\title{
ON THE INNOCENCE OF HISTORIOGRAPHY: JOHANNES SAMBUCUS' EMBLEM ABOUT THE DIFFERENCE BETWEEN GRAMMAR, DIALECTICS, RHETORIC, AND HISTORY
}

\author{
DÁVID MOLNÁR \\ Research fellow, MTA-ELTE Humanism in East Central Europe \\ Lendület Research Group \\ Eötvös Loránd University, Faculty of Humanities \\ david.molnar@gmail.com
}

\begin{abstract}
This paper examines the iconolographical origin of Johannes Sambucus' emblem dedicated to Carlo Sigonio, which - according to its title - displays the difference between grammar, dialectics, rhetoric and history. I focus on the central female figure whose innocent nudity represents the truth and whose connection with the ideal historiography standing - balancing together with Dialectics and Rhetoric on the head of the young virgin Grammar. The special relationship between History and naked truth also defines its symbolic connection with the costumes of the other two figures: Dialectics in rough working clothes and Rhetoric in her long luxury dress. Three symbolic animals also belong to the three female figures: a sphinx to Dialectics, a chimera to Rhetoric and a winged dog to History. Contextual examination of the emblem reveals the possible source of the strange winged dog symbol is Plutarch's short story of Osiris and Isis. In addition, the paper draws attention to an ironic twist of History in connection with Carlo Sigonio that shows that its nudity is not always so innocent.
\end{abstract}

Keywords: emblem, Sambucus, Sigonio, Plutarch, Osiris, Isis, historiography, winged dog, time, nudity

Johannes Sambucus published in 1564 his emblematic work Grammaticae, Dialecticae, Rhetoricae, Historiae differentia (The difference between grammar, dialectics, rhetoric and history), ${ }^{1}$ which he dedicated to Carlo Sigonio (1522/1523-1584), a humanist of Modena (Figure 1). ${ }^{2}$ Although a group of female figures worthily symbolizes Sigonius, an illustrious professor of rhetoric, philologist, teacher of Greek, and publisher of historical works, worthy of note is the middle figure - ostentatious with her innocence and honesty but naked - Historia and close to her the image of a winged dog. Since I have not encountered either the representation of Historiography naked or the winged 
dog related to her prior to the emblem associated with the figure of Sambucus, I hypothesize that they first appeared in his emblem book. Unless Sambucus was endowed with foresight, he did not know that this female figure would, due to a strange coincidence of accidents, call into question the purity of historiography and faith in the purity of history. Below is the poem relating to Historia:

Sunt tres praestantes diversa veste puellae, / Nituntur hae puellula ut crepidine. / Simplex historia est, lux, custos temporis, atque / Veri parens, quae gloriam tribuit bonis. / Gratia non ducit, propriis affectibus obstat: / Nil iudicans, alios reliquit iudices. / Ordine simpliciter geritur quod narrat ab ovo, / Hanc pone rhetorica est sequens loquacior. / Quae coram recitat foecundas iudice lites, / Vestita longo syrmate atque obambulat. / Et studet efficto lucrari schemate caussas, / Dum se venustis venditat coloribus. / Quod manibus tantum planis, longa et petit hasta: / Premendo nil urgens suaviter liget. / Aspera, non habitu sequitur Dialectica culto, / Sagaciter verum eruens puteo abditum. / Cominus adgreditur, vitum et complexibus arctat, / Nunquam remittere iure de suo volens. / Nam pungit, laqueo et captat, ratione regitque, / Trux vinculo illigat potenter anxio. / Assimilata fuit variae quoque lumine Phoebi, / His sed parum iuvabere absque grammatis. / Illa etenim solidi sunt fundamenta laboris, / Grammaticae iners statuet nihil perenniter. / Historia ut canis alatus, Rhetorque Chimaera, / Sphynx Logice, tenet has Virgo, columna teres. ${ }^{3}$

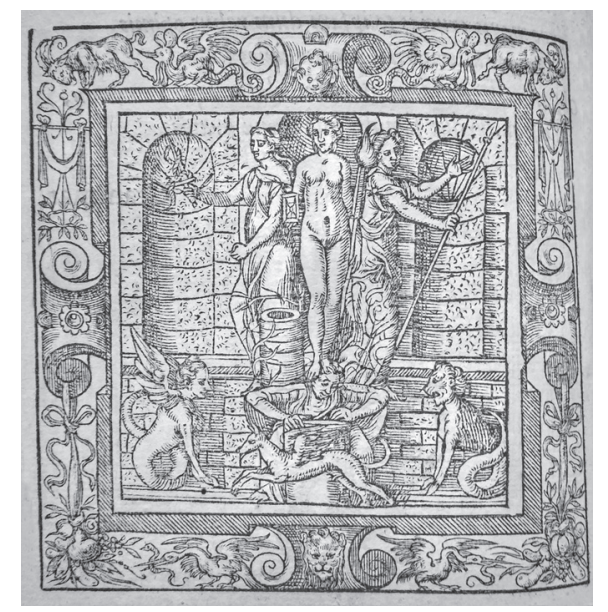

Figure 1:

Grammaticae, Dialecticae, Rhetoricae, Historiae differentia

(Emblemata 1564, 142)

In the following lines of the epigram, Sambucus contrasts Historia's simplicity with the clothes of Rhetoric and Dialectics. At the end of the poem, he adds 
three mythical creatures to the female figures: a chimera to Rhetoric, a sphinx to Dialectics, and a winged dog to History. Sambucus clearly connects to the iconographic tradition that depicts Truth as a naked woman. ${ }^{4}$ The word simplex, relating to Historia, means 'plain, artless, honest, ingenuous'; Sambucus - or the illustrator - emphasizes this simplicity and plainness with nudity that compounds the traditional figure of Historia with Veritas. ${ }^{6}$ These would be evident for a humanist scholar. Aristotle articulates this sentiment in Poetics (1451a36-1452a11), writing that the historiographer tells of events that have happened while the poet tells only those which can happen. Although the figure of Historia - who openly reveals facts and sometimes serves actual political intentions - intertwines shamelessly with the traditional figure of nuda Veritas and the veritas simplex (changed to historia simplex by Sambucus), the two figures cannot be allowed to blend with each other, because ultimately - as we will see later - Truth can judge over Historiography but Historiography cannot do this to Truth.

In both the poem and illustration, the clothes of the female figures are central. The nudity of Historia reaches its symbolic meaning only when contrasted with the dress of Rhetoric and Dialectics. The coarse weave dress of rough (aspera) Dialectics is working clothes worn because of her hard work trying to dig out the truth like hidden water drawn from a well (puteus, also appearing in the image). ${ }^{7}$ She forcefully corners and ties up her opponent with the snare (which appears as a dagger in the illustration) and chain of exhausting rational argument. ${ }^{8}$ The body of the female figure is none other than the hidden truth screened behind the coarse veil of logic and rationality. No one wants to win her heart. Dialectics, however, drags away and violates her "victim" who perhaps does not suspect that under the rough, unassuming and sweaty clothes, a more desirable Truth is concealed.

In contrast, Rhetoric wears a syrma, the long dress of actors of antique tragedy whose long train - probably a reference to her talkativeness - trails along the ground (though it is not shown in the illustration). Rhetoric tries to sell (venditat) herself while walking in front of the listeners in her fashionable and colourful dress. She is the celebrated diva who attracts attention with her elegant and luxurious clothing. Her talkative exterior ingratiates herself with everyone, and with this false illusion, she wants to be loved by all those around her. Although she holds a spear, she does not need any weapon to get what she wants: she gently, almost unnoticed, ties up the listener. As indicated by her inviting, open palm, she obtains everything without violence. In contrast to Dialectics, her "victims" give themselves willingly; none however can know for sure the nature of her real, naked body, the Truth hidden under the rhetorical copiousness of the ornamented and beautiful dress.

Compared to them, Historia - that is historiography (and perhaps history as well) - is naked, measuring time with an hourglass and supposedly wanting to show only the naked "truth". With nothing to hide, she stands, simple and honest, 
naked in front of her judges. The torch she holds in one hand gives light so that nothing on her body shall be hid. In this manner, she shows her form as Truth. However - as the epigram also states - she leaves the judgement of her body to someone else (Nil iudicans, alios reliquit iudices). Ultimately, she leaves the sentence to Veritas herself, who reveals all truth after some time. There is a big difference between them: Historia would just peek under another's clothes, while Veritas would pull their dresses down.

The hourglass of the emblem clearly refers to time. Later, Cesare Ripa - who must have known Sambucus's work also mentions the hourglass among the attributes of Verità since, sooner or later a concealed truth will be brought to the surface by time. As a consequence, it was frequently represented together with Cronos. (This is significant in connection with the dedication and interpretation of this emblem. $)^{9}$

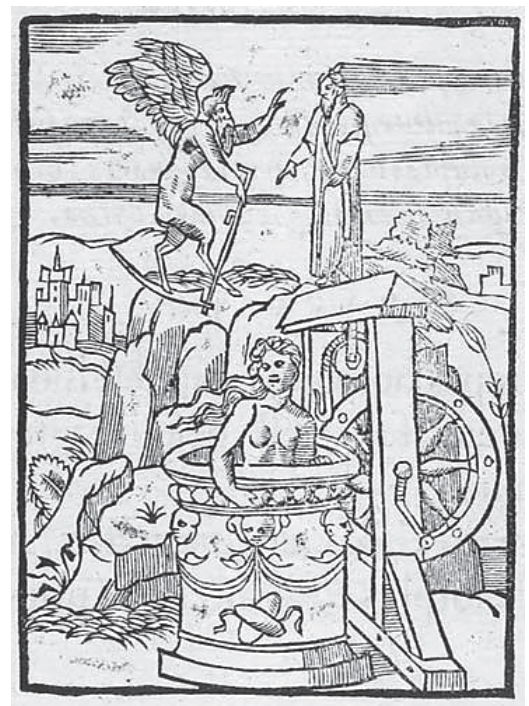

Figure 2:

Guillaume de La Perrière, La morosophie, 48

Regarding Historia, it is worth recalling the figure of Clio, the muse of historiography. While traditionally she does not appear nude, among her attributes can be found a parchment scroll and stylus, as well as the trumpet or the lute by which she trumpets - as Sambucus's Historia does too - the reputation of excellent people abroad. ${ }^{10}$ The comparison of the Sambucus figure with Clio is not groundless because we encounter a similar image in Martianus Capella's On the Marriage of 
Philology and Mercury (2.122), in which the muse addresses Philologia. However, the author referred to her as rhetor! Sambucus certainly knew of Martianus Capella, and he knew that his educated target audience would understand the reference. Martianus associates Clio with rhetoric: her singings about her rhetorical babble uses the word syrmate, ${ }^{11}$ hardly known in the Latin corpus, that originated from the aforementioned syrma. Martianus does not allude to the nudity of Clio.

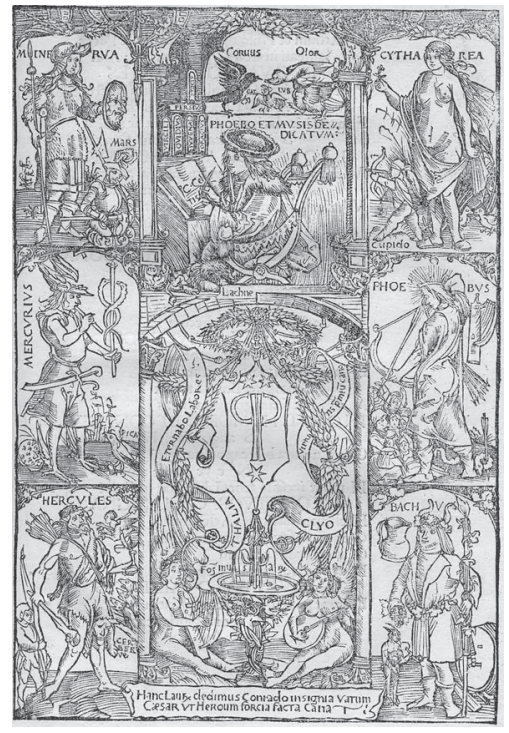

Figure 3:

Conrad Celtis, Amores, vii ${ }^{\mathrm{r}}$

I have managed to find the figure of the unclothed Clio predating Sambucus's Emblemata in only two places. The first is mentioned solely as a matter of curiosity since it is unlikely to concern Sambucus. This is Raffaello's fresco Parnassus located in the Apostolic Palace in the Vatican. While Clio is not entirely naked here either, in the chorus of the muses, she is the only one who discloses her bosom. Therefore it does not seem too bold to suggest that we observe in this work the attribute of the nakedness regarding the muse. The other more probable source is Conrad Celtis's 1502 work, the Amores (Figure 3). ${ }^{12}$ The engraving placed at the beginning of the book depicts the author himself and goddess Philosophia (viir). Surrounded by books, the inspired Celtis is shown writing words dictated by Apollo and the muses (Phoebus et Musis dedicatum). Also the fountain of inspiration is visible, next to which in reference to Celtis's historiographical works, Thalia and the naked Clio sit plucking a harp and a lute. ${ }^{13}$ 
The Celtis picture and Sambucus's three symbolic animals are reminiscent of Francesco Gafori's illustration of the Neoplatonic cosmos at the beginning of his Practica musicae from 1496 (Figure 4). ${ }^{14}$ The two lowermost muses in the row are Clio and Thalia visible under the three-headed serpent. Thalia represents one of the essentials of the created material world: time. The former can be found at the border of the sublunary world, while the latter - connecting to the element of earth - is under the sublunary sphere. Gafori's illustration also pictures the all-devouring time dragon.

This refers to the $5^{\text {th }}$-century Neoplatonic author Macrobius. An ekphrasis can be read in his Saturnalia (1.20.13-15) about a statue of the Egyptian god Serapis who lays one of his hands on the three-headed creature next to him that has entwined his own draconic body as a serpent. The middle head of the three-headed creature is that of a lion, the right a dog, the left a wolf, representing according to Macrobius time in its three aspects: the present, the future, and the past respectively. This creature devours time with its three heads.

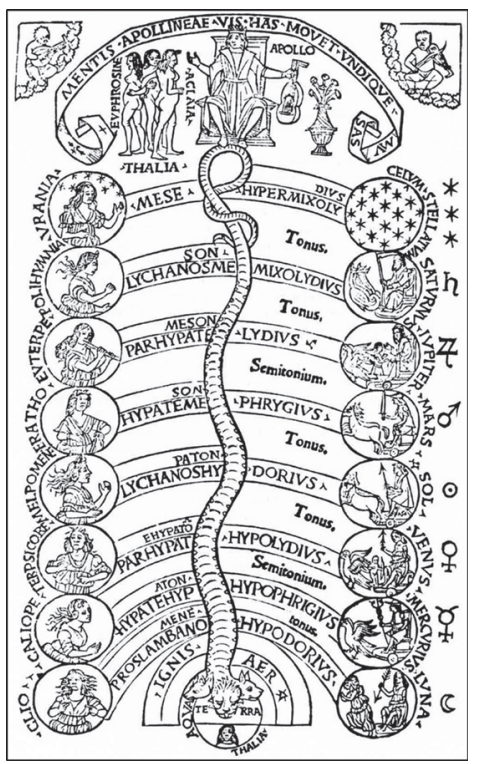

Figure 4:

Franchino Gaffurio, Practica musicae, $\Gamma^{\mathrm{r}}$

Sambucus' emblem recalls this already commonplace $16^{\text {th }}$-century image from Macrobius: the dragon of time. ${ }^{15}$ Although historia has a clear connection with passing time, even with the greatest goodwill, the three figures of the illustration 
just refer to the image of Macrobius. According to the lines of Sambucus, the difference is clear: under the figure of Historia there is no wolf symbolizing the past, but rather a winged dog (canis alatus) that can lead us to time which is closely related to historiography or history. The aforementioned veritas and tempus link with each other in the figure of the emblem, because time is often represented as an old man or Cronus. ${ }^{16}$

Hidden is the connection between the figure of "winged dog" and History. Egyptian mythology depicts the god Anubis with a dog's head (or, rather, in the figure of the sacred animal that represents him, the dog). The probable source of Sambucus is the short story of Osiris and Isis in Plutarch's Moralia (368E3-F5): ${ }^{17}$

\begin{abstract}
When Nephthys gave birth to Anubis, Isis treated the child as if it were her own; for Nephthys is that which is beneath the Earth and invisible, Isis that which is above the earth and visible; and the circle which touches these, called the horizon (ópí̧ $\omega v$ ), being common to both, has received the name Anubis, and is represented in form like a dog; for the dog can see with his eyes both by night and by day alike. And among the Egyptians Anubis is thought to possess this faculty, which is similar to that which Hecate is thought to possess among the Greeks, for Anubis is a deity of the lower world ( $\chi$ Өóvios) as well as a god of Olympus ('O $\mathrm{\lambda} 0$ $\mu \pi 1 \mathrm{~s})$ ). Some are of the opinion that Anubis is Cronus

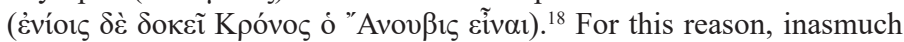
as he generates all things out of himself and conceives all things within

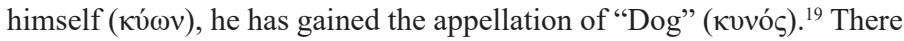
is, therefore, a certain mystery observed by those who revere Anubis; in ancient times the dog obtained the highest honours in Egypt. ${ }^{20}$
\end{abstract}

This interpretation of Anubis is possibly an invention of Sambucus. ${ }^{21}$ By simply replacing Cronus, represented as an old man, with Anubis, represented as a dog, while keeping the wings of Cronus which symbolize the flight of time, the winged Anubis, symbolizing the most important attribute of the nude Historiography - the passage of time - was born. Based on Christophe Plantin's accomplished edition, the direction that the winged creature faces can also be regarded as deliberate: the animal faces left - the direction of time past.

Sambucus assembled the figure of Historia shown in the emblem from the nude Verity, the straight-talking Clio, as well as the winged Cronus and its Orphic version, Anubis, known from Plutarch. Clio is particularly important in order to understand the aspect of Historia that wants to grab time because the mother of all muses is Mnemosyne, the goddess of remembrance. As a result, Historia (like Conrad Celtis's Clio) does not just remember, but also reminds us with her own nudity of bare occurred events as she tries to hold, or even guide, the winged dog - that is the all-devouring time - on a leash. Consequently, the memory of Historiography - while it places the occurred events of the past as truth for us - often 
remakes and reconstructs them, hiding them in carnival costumes and pretending that they are naked.

In this regard, it is worth noting the perhaps intentional expression veri parens in Sambucus's poem. According to this phrase, Historia can be interpreted as the 'author of truth' or even the 'inventor, fabricator of that'. Based on the text, all three female figures are balancing on the back of the virginal and innocent Grammar. With Sambucus highlighting the virginity of Grammar (tenet has Virgo), he also deprives the other three figures of this status. So even then the all-revealing, judicial and simple Historia is not a virgin! Although she honestly shows everything, and we get what we see, she - as we can read - does not give herself to anybody, so she is untouched; however, if she does not give herself to anybody, then why she is not a virgin? Could it be that this is only the pretence of untouched chasteness? Who can tell this just by looking at her? It is as if we had entered a reverse of Andersen's tale in which the nudity of the emperor is seen by everybody as only a skilfully sewed masquerade.

History itself also had words for Sambucus's emblem by showing with an ironic twist that the nudity of Historia was not so innocent. Sambucus dedicated his emblem to a humanist predominantly known as a historiographer and a reputable publisher of ancient historical texts. Sambucus could not have known that around two decades after the publication of the edition Sigonio would be embroiled in one of the greatest forgery scandals of the age. He was accused of writing Cicero's De consolationei, believed lost until the editio princeps was published in 1583. ${ }^{22}$ Sigonio claimed this was the original work of Cicero, denying any accusation of forgery throughout his life. Contemporaries doubted the authenticity and origin of the text; at present, it is widely considered to be a forgery - though what role Sigonio played in producing the text is unresolved. ${ }^{23}$

Sambucus could not have foreseen that Sigonio, as the "keeper of time" (custos temporis), would bring to light something that perhaps had never existed before. Because of the charge of forgery, nuda historia clashed against nuda veritas. In creating or rewriting one episode of history, Carlo Sigonio lost his innocence. Due to the dedication of the emblem, he dragged down with him the nude Historia anxious to preserve her own honour. Though nudity can - at least with the pretence of cleanliness - dress up anybody, it seems that we cannot confirm whether the participants of this carnival are really nude or whether their apparent nudity is just the garb of a carnival costumes.

Notes

1 Ioannes Sambucus, Emblemata (Antwerpen, Ch. Plantin, 1564), 142-143.

2 William McCuaig, Carlo Sigonio: the changing world of the late Renaissance (Princeton, N. J., Princeton University Press, 1989). 
3 "Here are three outstanding girls with different clothes, and these stand on a little girl as a base. History is plain, a light, guard of time, and mother of truth - she grants glory to the virtuous. Favour [sc. Partiality] does not lead her; she resists her own emotions; judging nothing, she leaves others to be the judge. What she tells from the beginning is openly presented. Following her from behind is the more talkative Rhetoric. And she delivers abundant lawcases in front of the judge, and walks about, dressed in a long syrma-robe. And she applies herself to gain her causes with a fashioned manner, while she tries to sell herself with charming colours [appearances]. She even approaches with a long spear what she could be done with open hands; she can bind up without pressing anything, pushing in an agreeable way. Dialectic follows, in a rough, unrefined style of dress perceptively digging out the truth that is hidden in a well. She approaches at close quarters, and binds the defeated with encirclings and never wants to let go of her law. For she jabs, catches with a snare, and rules through reason; with a meticulous chain the harsh lady forcefully ties up. She also was variously likened to the brightness of Apollo, but without grammar you will find insufficient help from these ladies. Those are the foundations of solid work, but when it lacks grammar, nothing will stand forever. History is like a winged dog, the Orator like a chimaera, Logic a sphinx, the virgin (girl) who holds them is like a rounded pillar." http://www.emblems.arts.gla.ac.uk/french/emblem.php?id=FSAb100

4 For example, the female figure of Truth under the title Fidei symbolum is nude in Andrea Alciati's emblem book, and the symbols of truth are also nude (ignuda) in Ripa's Iconologia: Andrea Alciati, Emblematum liber (Augsburg, H. Steyner, 1531), E7; Cesare Ripa, Iconologia (Rome, Heredi di Gio. Gigliotti, 1593), 284-286.

5 See the dedication of Sambucus' edition of Bonfini to Maximilian II in 1568, where he summarizes his conception of "historia pura et vera", especially its comparison with rhetoric, and - instead of dialectics - poetry: "Quare poeta semper imitator; pugnax orator et argumentosus;

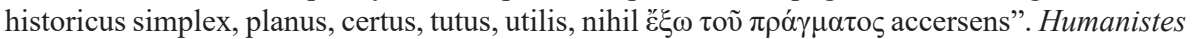
du bassin des Carpates: II. Johannes Sambucus, eds. Gábor Almási, Farkas Gábor Kiss (Turnhout, Brepols, 2014), 102-109.

6 The question arises how much influence Sambucus had on the finished illustration. In the summer of 1563 he commissioned the design of the drawings of his Emblemata from the popular Flemish poet and portraitist Lucas de Heere. Sambucus probably met him personally in Gent and in the first stage was likely able to supervise the engravings. For some reason however, Sambucus gave the printing privilege to Plantin in 1564 and was not subsequently involved in the work. Heere - supposedly with the contribution of Sambucus - made 168 illustrations, of which Plantin had 80 redrawn by Pieter Huys and Geoffroy Ballin. It cannot be known which of these were redrawn and to what extent. Arnoud S. Q. Visser, Joannes Sambucus and the Learned Image: the Use of the Emblem in Late-Renaissance Humanism (Leiden, Boston, Brill, 2005), XXV-XXX, 62-83, 225-228. In this regard, it is worth mentioning Valeriano's Hieroglyphica surely known by Sambucus - which used the word simplex to describe the nude Veritas. Pierio Valeriano, Hieroglyphica (Basel, [M. Isengrin], 1556), 326 ${ }^{\mathrm{v}}$.

7 See e. g. La Perrière's emblem no. 48 (Figure 2), where Truth, hidden in the well, is not found by her father, and the winged Time that reaps everything: Guillaume de La Perrière, La morosophie (Lyon, M. Bonhomme, 1553), 48.

8 The word sphinx also calls up the chain of Dialectics as it is derived from the Greek verb $\sigma \varphi$ í $\gamma \omega$ that means to "bind tight, hold together, press". In the same manner, Dialectics strangles with its logical and rational arguments and debate skills. In addition, according to one version of its mythological stories, the sphinx also received her riddles from the muses (see below Clio). Károly Kerényi, Görög mitológia (Budapest, Gondolat, 1977), 248-249.

9 See the aforementioned emblem of La Perrière, as well as Annibale Caracci's 1585 painting on the allegory of truth and time (London, Windsor Castle, Royal Collection), where the naked 
Truth - while resting against the winged old Time - stamps on a dressed woman. Another interesting painting is Samuel van Hoogstraten's The triumph of Truth (Finspång Castle, Sweden) in which the winged time as Cupid emerges from behind the drapery. He appears by the shoulders of the nude Truth whilst a richly clothed figure - with a mask on his belt - flees out of the framed picture.

10 See Cesare Ripa, where Clio holds a trumpet in her one hand, and a volume of Thucydides in the other hand: Cesare Ripa, Iconologia (Rome, L. Faeius, 1603), 346.

11 "Tu quae Rhetorico clangere syrmate."

12 Conrad Celtis, Quatuor libri amorum (Nuremberg, 1502).

13 Celtis, Id., avi ${ }^{\mathrm{v}}$-aviir. See for this: Clio gesta canens transactis tempora reddit. - In: Alexander Riese (Ed.): Anthologia Latina (Leipzig, Teubner, 1906), I.2, 134 (No. 664). It is worth noting the seven muses gathered by the feet of Apollo are all dressed. Ulrich Pfisterer, The Muses ' Grief: Jacopo de'Barbari on Painting, Poetry and Cultural Transfer in the North. - In: Kathleen W. Christian, Clare E. L. Guest, Claudia Wedepohl (Eds.): The Muses and their Afterlife in Post-Classical Europe (London-Torino, The Warburg Institute-Nino Aragno Editore, 2014), 85-89.

14 Franchino Gaffurio, Practica musicae (Milan, per Gulielmum Signer Rothomagensem, 1496), $\Gamma i^{r}$.

15 In this regard, also see the oft cited ,all-devouring time” (tempus edax rerum) topos of Ovid (Met., 15.234-236): and Titian's allegory of Prudence (London, National Gallery). In his epic Africa (3.156-164), Petrarca describes the creature in the same manner, but instead of Serapis, he mentions Apollo (see Gafori's illustration) and speaks about the serpent that symbolizes "fleeing time" (fugientia tempora). It appears as a symbol on an emblem of Colonna: Francesco Colonna, Hypnerotomachia Poliphili (Venice, Manutius, 1499), yr. Sambucus's Emblemata was published only eight years after Valeriano's Hieroglyphica, in which the wording "Sol" (referring to Phoebus Apollo) can be seen above the illustration of the three-headed figure (triceps Serapis) mentioned as the symbol of time by Valeriano as well: Id., 229A-B.

16 See the previously mentioned emblem of La Perrière, Carracci's painting and The Triumph of Truth by Rubens (Paris, Louvre). The appearance from the $15^{\text {th }}$-century of Saturnus with hoofed feet and a scythe is based on a false etymology of the word "satyr". The first such printed illustration appears in Charles Estienne's anatomical book: Carolus Stephanus, De dissectione partium corporis humani (Paris, S. de Colines, 1545), ${ }_{*} . \mathrm{i} . \mathrm{r}$.

17 Sambucus does not mention Plutarch in his dedication (see endnote 6).

18 Plutarch might be referring here to the Orphic tradition.

19 Plutarch plays with the participle of $\kappa$ w $\omega$ (be pregnant with) and the homonymic noun form of

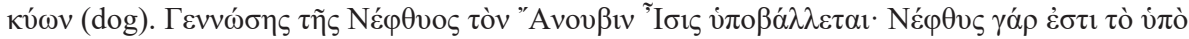

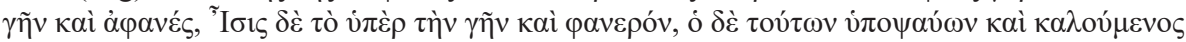

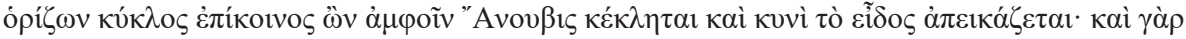

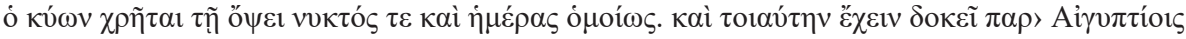

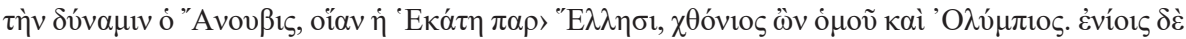

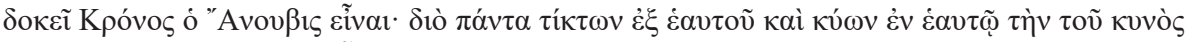

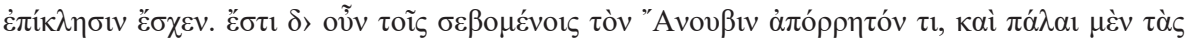

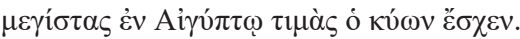

20 Translation by Frank Cole Babbitt: Plutarch, Moralia (London, Heinemann, 1984), 106-107.

21 I have encountered the figure of the winged Anubis only once: in the $17^{\text {th }}$-century fresco in the Egyptian room in Villa Borghese in Rome by Tommaso Maria Conca.

22 Cicero, Consolatio liber quo se ipsum de Filiae morte consolatus est (Venice, H. Polus, 1583).

23 Evan Taylor Sage, The Pseudo-Ciceronian Consolatio (Chicago, Chicago University Press, 1910). McCuaig, Id., 303-346. Richard S. Forsyth, David I. Holmes, Emily K. Tse, "Cicero, Sigonio, and Burrows: Investigating the Authenticity of the Consolatio", Literary and Linguistic Computing 14/3 (1999): 375-400. 